\title{
Administration of Echinococcus granulosus protoscoleces by different ways in mice and detection of serological responses*
}

\author{
Bünyamin İREHAN ${ }^{1}$, Ergün KÖROĞLU ${ }^{2}$, Sami ŞIMŞEK ${ }^{2}$ \\ ${ }^{1}$ Veterinary Control and Research Institute, Parasitology and Bee Diseases Laboratory, Elazığ; ${ }^{2}$ University of Firat, Faculty of \\ Veterinary Medicine, Department of Parasitology, Elazığ, Turkey.
}

\begin{abstract}
Summary: This study was planned for the aim of administration of hydatid cyst protoscoleces in Albino Balb/c mice in different ways for the formation of experimental hydatidosis and detection of serological response. For this purpose, the protoscoleces which were collected from sheep liver infected with hydatid cyst were divided into four experiments and one control group following to viability test. Protoscoleces were administrated by the way of intraperitoneal, subcutaneous, ocular and oral routes. In the control group, physiological saline was applied intraperitoneally. At the end of the experiment period (5 months) live mice were sacrified and some internal organs (lungs, liver, hearth, spleen, kidney and brain) were collected and those were examined both macroscopically and also microscopically by using of pathological tissue sections for hydatid cysts. Besides, blood samples were collected for the aim of the investigation of antibodies against hydatid cyst antigens by indirect-ELISA. On the 60th day of the study, sterile hydatid cysts which size of 2-2.5 cm diameter localized on right and left kidney of a died mouse were found in intraperitoneal group. Due to unable to complete the study process of mouse, serum samples couldn't be received. Sterile hydatid cysts were macroscopically detected in three mice in subcutan group and seropositivity was found by ELISA in all. It was observed neither macroscopic nor microscopic hydatid cysts in ocular group while seropositivity was detected in five mice. Similarly, neither macroscopic nor microscopic hydatid cysts were detected in oral group while seropositivity was observed in three mice. There was no any hydatid cyst formation and seropositivity in control group.

Keywords: Echinococcus granulosus, ELISA, experimental infection, hydatid cyst, mice.
\end{abstract}

\section{Farelerde Echinococcus granulosus protoskolekslerinin farklı yollarla uygulanması ve serolojik yanıtın belirlenmesi}

Özet: Bu çalışma, Albino Balb/c türü farelerde hidatik kist protoskolekslerinin farklı yollarla verilmesiyle deneysel hidatidozis oluşturulması ve serolojik yanıtın belirlenmesi amacıyla planlanmıştır. Bu amaçla, hidatik kist ile enfekte koyun karaciğerinden elde edilen protoskoleksler canlılık tayininden sonra dört deney ve bir kontrol grubuna uygulandı. Protoskoleksler periton içi, derialtı, göz ve ağız yoluyla uygulandı. Kontrol grubuna periton içi olarak fizyolojik su uygulandı. Deney süresinin sonunda (5 ay) canlı fareler uyutularak bazı iç organları (akciğerler, karaciğer, kalp, dalak, böbrek ve beyin) alındı ve hem makroskobik olarak hem de doku kesitlerinde mikroskobik olarak hidatik kist varlığı yönünden muayene edildi. Bunun yanısıra hidatik kist antijenlerine karşı oluşmuş antikorların indirekt-ELISA ile araştırılması amacıyla kan örnekleri alınmıştır. Çalışmanın 60. gününde periton içi grupta ölü bulunan bir farenin sağ ve sol böbreğinde 2-2.5 cm çapında steril hidatik kistler bulunmuştur. Çalışma sürecini tamamlayamayan farelerden serum örneği alınamamıştır. Derialtı gruptaki üç farede makroskobik olarak hidatik kistlere rastlanmış ve üçünde de ELISA ile seropozitiflik belirlenmiştir. Göz grubunda ne makroskobik ne de mikroskobik olarak hidatik kistlere rastlanmazken farelerin beşinde seropozitiflik belirlenmiştir. Benzer şekilde ağız grubunda ne makroskobik ne de mikroskobik hidatik kistler gözlenmezken üç farede seropozitiflik elde edilmiştir. Kontrol grubunda herhangi bir kist oluşumu ve seropozitiflik belirlenmemiştir.

Anahtar sözcükler: Deneysel enfeksiyon, Echinococcus granulosus, ELISA, fare, hidatik kist.

\section{Introduction}

Hydatidosis is a zoonotic diseases caused by the metacestod of Echinococcus granulosus. The larva named as hydatid cyst shows a low degree of host specificity and numerous species of herbivorous or omnivorous animals are intermediate hosts. They become infected by ingestion of eggs (oncospheres) in contaminated food or water (primary infection). The fully developed larva is an unilocular fluid-filled cyst may contain protoscoleces. These are the infective stage of the parasite in the definitive host, but they are also able to differentiate asexually into secondary cysts when they are released through accidental rupture of the primary cyst (13). In vivo studies aimed at understanding the

\footnotetext{
* This study is summarized from the master thesis of first author.
} 
immunobiology of the interaction between the $E$. granulosus metacestode and its host have mainly used the murine model of secondary infection since it has the advantage of avoiding the handling of oncospheres $(4,5)$. Hydatid cysts develop different mechanisms for avoiding the cytotoxic effects of the immune response of hosts. The coexistence of the chronic infection with detectable humoral and cellular responses against the parasite represents one strategy of the host-parasite relationship (2). Considering the fact that hydatid cysts can be ruptured so that protoscoleces can be squirt all over the surgeon, slaughterer and lab workers face and clothes. According to the low possibility fluid of may be cause ocular hydatidosis (1). The personal opinion that it can cause ocular hydatid cyst. During the recent years, numerous studies have been carried out in the forms of in vivo and in vitro on the E.granulosus, and some experimental models have been done to make secondary hydatid cysts (5).

This study was carried out for the aim of administration of sheep hydatid cyst protoscoleces in Albino Balb/c mice by the ways of intraperitoneal, subcutaneous, ocular and oral routes for the formation of experimental hydatidosis and detection of serological response. Besides, macroscopic and microscopic examination of cysts and detection of serologic response also aimed.
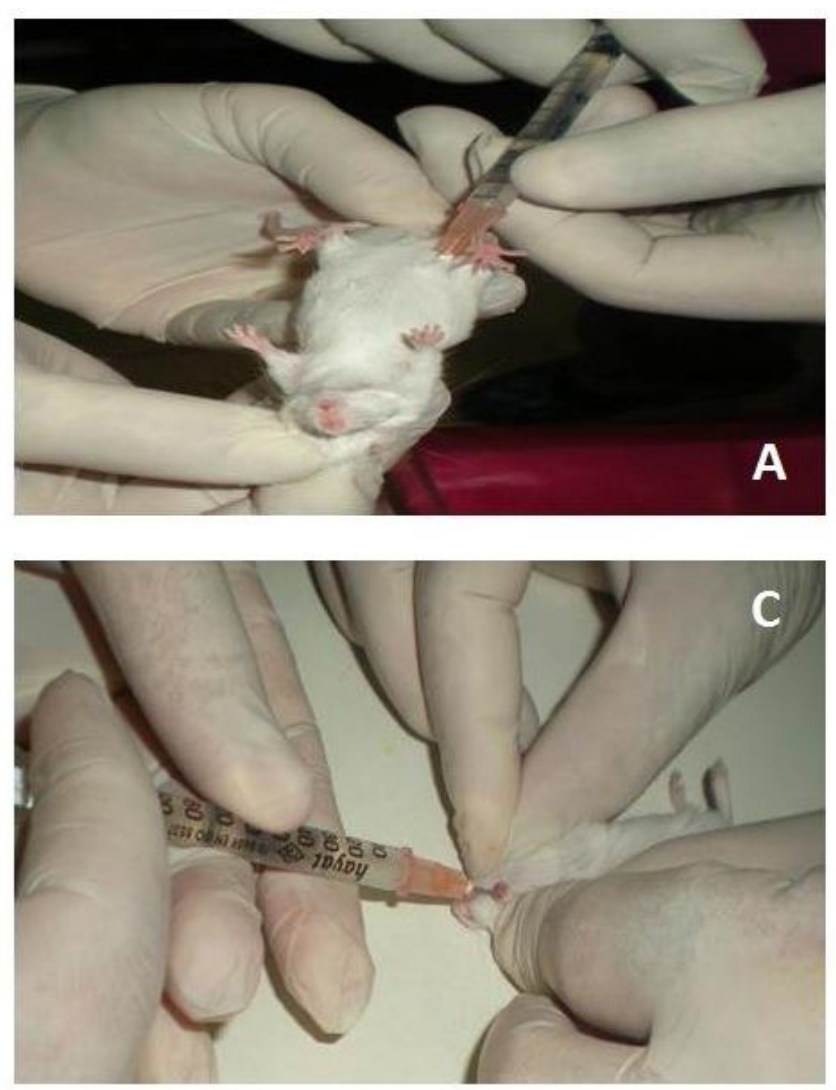

\section{Material and Methods}

Sheep liver infected with hydatid cyst were collected from a slaughterhouse in Elazig province and transferred to laboratory. The hydatid cyst fluid was aspirated examined for presence of protoscoleces. The viability of protoscoleces was determined by flame cell activity with staining by $0.1 \%$ of eosin and $0,03 \%$ methylene blue (11). Viability over $90 \%$ protoscoleces were used for the experimental infection. Then 2000 protoscoleces $/ 1 \mathrm{ml}$ in physiological saline were prepared for injections. $100 \mathrm{IU} / \mathrm{ml}$ Penicillin G (potassium salt) and $200 \mu \mathrm{g}$ Streptomycin Sulphate were also added to the injection solutions. Balb/c mice maintained in the Experimental Research Center of Firat University were used for the study. The mice were divided into five groups and each of contained seven. The injected solutions and routes have been shown in Table 1 and Figure 1.

Mice were fed with ad libitum into cages and death mice during the experiment (5 months) were examined for hydatid cysts both macroscopic and microscopic examinations. After 5 months, the mice were examined for clinical symptoms and after anesthetize by diethyl-ether and euthanasied with servical dislocation. Blood samples and lungs, liver, hearth, spleen, kidneys and brain were collected in all groups and the eyes were enucleated in ocular group as well. All organs were
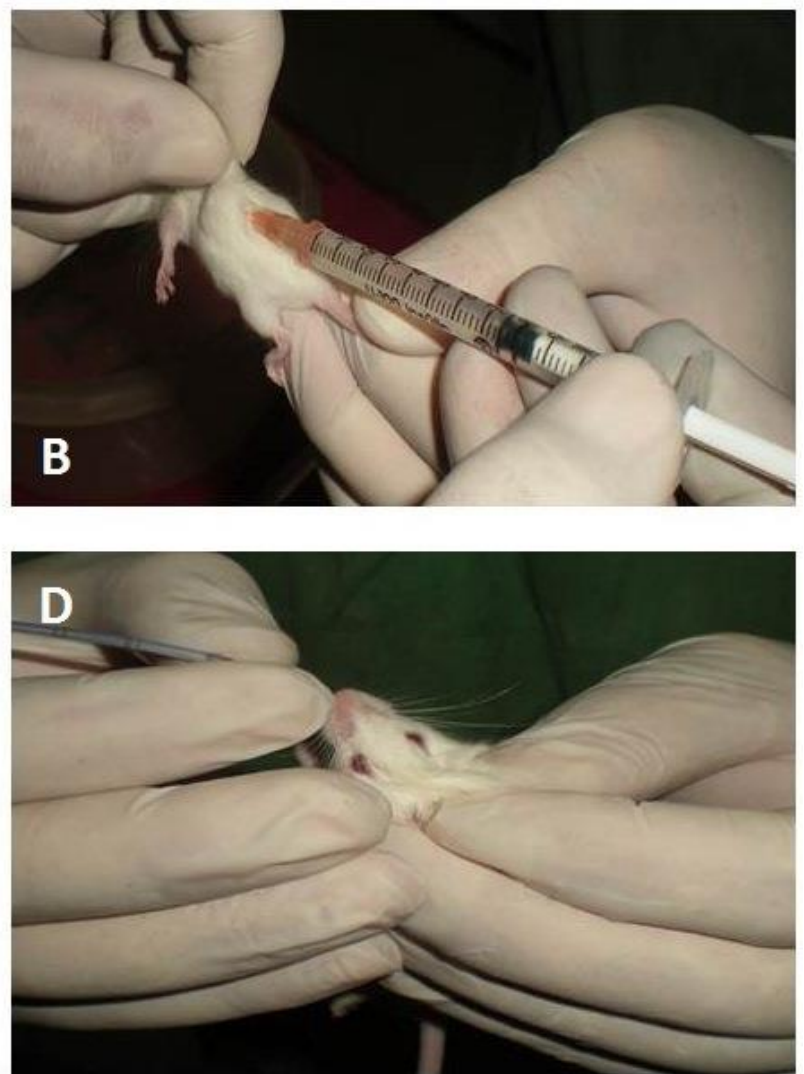

Figure 1. Administration of protoscoleces to mice by different routes. A: Intraperitoneal, B: Subcutan, C: Ocular, D: Oral. Şekil 1. Protoskolekslerin farelere farklı yollarla uygulanması. A: Peritoniçi, B: Derialtı, C: Göz, D: Ağız. 
Table 1. Injected solution and the routes in experiment and control groups.

Tablo 1. Deney ve kontrol gruplarında enjekte edilen solüsyonlar ve uygulama yolları.

\begin{tabular}{|c|c|c|c|c|}
\hline Groups & Solutions & Injected amounts & Injection routes & No of subjects \\
\hline Intraperiton & 2000 protoscoleces $/ \mathrm{ml}$ & $0,5 \mathrm{ml}$ & $\begin{array}{c}\text { Intraperitoneal injection } \\
\text { (Figure 1A) }\end{array}$ & 7 (3 males, 4 females) \\
\hline Subcutan & 2000 protoscoleces $/ \mathrm{ml}$ & $0,5 \mathrm{ml}$ & $\begin{array}{l}\text { Subcutan injection in back region } \\
\text { (Figure 1B) }\end{array}$ & 7 (4 males, 3 females) \\
\hline Eye & 2000 protoscoleces $/ \mathrm{ml}$ & $0,2 \mathrm{ml}$ & $\begin{array}{l}\text { Intraocular injection } \\
\quad \text { (Figure 1C) }\end{array}$ & 7 (4 males, 3 females) \\
\hline Oral & 2000 protoscoleces $/ \mathrm{ml}$ & $0,5 \mathrm{ml}$ & Gavage with oral probe (Figure 1D) & 7 (3 males, 4 females) \\
\hline Control & Physiological saline & $0,5 \mathrm{ml}$ & $\begin{array}{l}\text { Intraperitoneal injection } \\
\text { (Figure 1A) }\end{array}$ & 7 ( 2 males, 5 females) \\
\hline
\end{tabular}

Table 2. Macroscopic and serologic findings in both experiment and control groups.

Tablo 2. Hem deney hem de kontrol grubundaki makroskobik ve serolojik bulgular.

\begin{tabular}{|c|c|c|c|c|c|}
\hline Groups & $\begin{array}{l}\text { Mice with } \\
\text { hydatid cyst }\end{array}$ & Organs with hydatid cyst & Serum & $\begin{array}{l}\text { Number of sera } \\
\text { collected mice at the } \\
\text { end of experiment }\end{array}$ & $\begin{array}{l}\text { Indirect- } \\
\text { ELISA } \\
\text { results }\end{array}$ \\
\hline Intraperiton & 1 & 1. Localized on the right and left kidneys & $\begin{array}{l}\text { could not } \\
\text { received }\end{array}$ & 1 & 1 negative \\
\hline Subcutan & 3 & $\begin{array}{l}\text { 1. Independent subcutanously on the back } \\
\text { region } \\
\text { 2. Localized subcutanously inside the back } \\
\text { region } \\
\text { 3. Localized intramuscular on the back } \\
\text { region }\end{array}$ & received & 4 & $\begin{array}{l}3 \text { positive } \\
1 \text { negative }\end{array}$ \\
\hline Eye & - & - & - & 7 & $\begin{array}{l}5 \text { positive } \\
2 \text { negative }\end{array}$ \\
\hline Oral & - & - & - & 6 & $\begin{array}{l}3 \text { positive } \\
3 \text { negative }\end{array}$ \\
\hline Control & - & - & - & 6 & 6 negative \\
\hline
\end{tabular}

examined for hydatid cysts by macroscopically and also microscopically in pathological sections. For this purpose tissues were fixed in $10 \%$ buffered formalin, routinely processed, and embedded in paraffin. The serial sections in 4-6 $\mu \mathrm{m}$ in thickness were stained with hematoxylin and eosin and Masson Trichrome (Biostain- UK) (6).

An Echinococcus granulosus antigen B enriched fraction was prepared from hydatid cyst fluid (HCF) obtained from sheep infected with hydatid cysts. The procedure was performed as previously described by Oriol et al. (8).

ELISA plates (Dynatech Laboratories, IA, USA) were coated with $100 \mu \mathrm{l}$ of $5 \mu \mathrm{g} / \mathrm{ml}$ of partially purified $\mathrm{HCF}$ antigens in $0.1 \mathrm{M}$ carbonate/bicarbonate buffer $(\mathrm{pH} 9.6)$ per well. Following overnight incubation the plates were washed twice with PBS containing $0.01 \%$ Tween-20 (PBS/Tween) and blocked with $130 \mu \mathrm{l}$ per well of a solution containing $5 \%$ skimmed-milk powder in $0.01 \mathrm{M}$ PBS (pH 7.4) for $1.5 \mathrm{~h}$ at $37^{\circ} \mathrm{C}$. After blocking, the plates were washing three times with PBS/Tween, 100 $\mu$ sera diluted 1:200 in PBS containing 0.05\% Tween20 were added to the wells and incubated for $1.5 \mathrm{~h}$ at 37 ${ }^{\circ} \mathrm{C}$. The plate was again washed five times and $100 \mu \mathrm{l}$ of a 1:7500 anti-mouse IgG peroxidase conjugate (Santa Cruz Biotechnology Catalog No: SC-358914) were added to the wells and the plate incubated at $37^{\circ} \mathrm{C}$ for $2 \mathrm{~h}$. Finally, after five washes, $100 \mu \mathrm{l}$ of substrate at a containing of O-phenylene diamine and hydrogen peroxide in citrate/phosphate buffer were added to each well conveniently readable results were obtained after 15 minutes incubation of room temperature. Enzymatic reaction was stopped with $50 \mu \mathrm{l}$ per well of $1 \mathrm{~N}$ sulphiric acid and the plate was read out $450 \mathrm{~nm}$ on an ELISA reader (Organon Teknika ELISA Reader). The results expressed as the mean of the optical density. All samples were worked duplicate and repeated which sera were different up to $10 \%$ between. Cut-off value was calculated as the mean of the negative control sera absorbance values plus 2 standard deviations $(9,10)$.

Animal ethical committee approval has been obtained by the author before the study was conducted.

\section{Results}

The macroscopic and serological results of the experiment are presented in Table 2. Six mice from intraperiton group were died during the experiment, with 
no clear reason. All of them were necropsied and hydatid cysts were seen on the right and left kidneys in only one case (died on 60th days). The size of isolated cysts in kidneys were varied from 2 to $2.5 \mathrm{~cm}$ (figure $2 \mathrm{~A}$ and $\mathrm{B}$ ). Microscopy of the cysts were shown in figure 2C and D. Serologic response couldn't be detected due to no serum sample handled. Only one mice completed the experiment period and there was no any hydatid cyst and antibody response.

In the subcutan group, three mice died and there were no any hydatid cyst both macroscopic and microscopic examinations. Only four mice completed the experiment period and hydatid cysts were detected three of them both macroscopic and microscopic examinations (Figure 2 E, F, G, H, I). All cysts were not fertile and antibody response was detected also three mice with hydatid cyst. All mice completed the experiment period in eye group. After necropsy hydatid cyst was not seen in the eye and around tissues of examined animals.
However, IgG antibody titre was detected in the five of seven mice. A mice died during experiment in oral group and six were completed. None of them had hydatid cyst while three mice were positive by ELISA. A mice was found alive in the cage and six were completed the experiment period in control group. There were no hydatid cysts neither macroscopic nor microscopic examinations and serologic response was negative in all six mice in this group.

\section{Discussion and Conclusion}

We have described here a mice model of secondary infection with E. granulosus protoscoleces by using of different application ways and relation with serologic response. Mousavi and Tappeh (7) prepared the different concentrations of protoscoleces and injected into the eyes of 60 mice for production of ocular hydatid cyst in mice. After 20 weeks, 10 mice died and the remaining 50 mice have been examined but there weren't any symptoms of

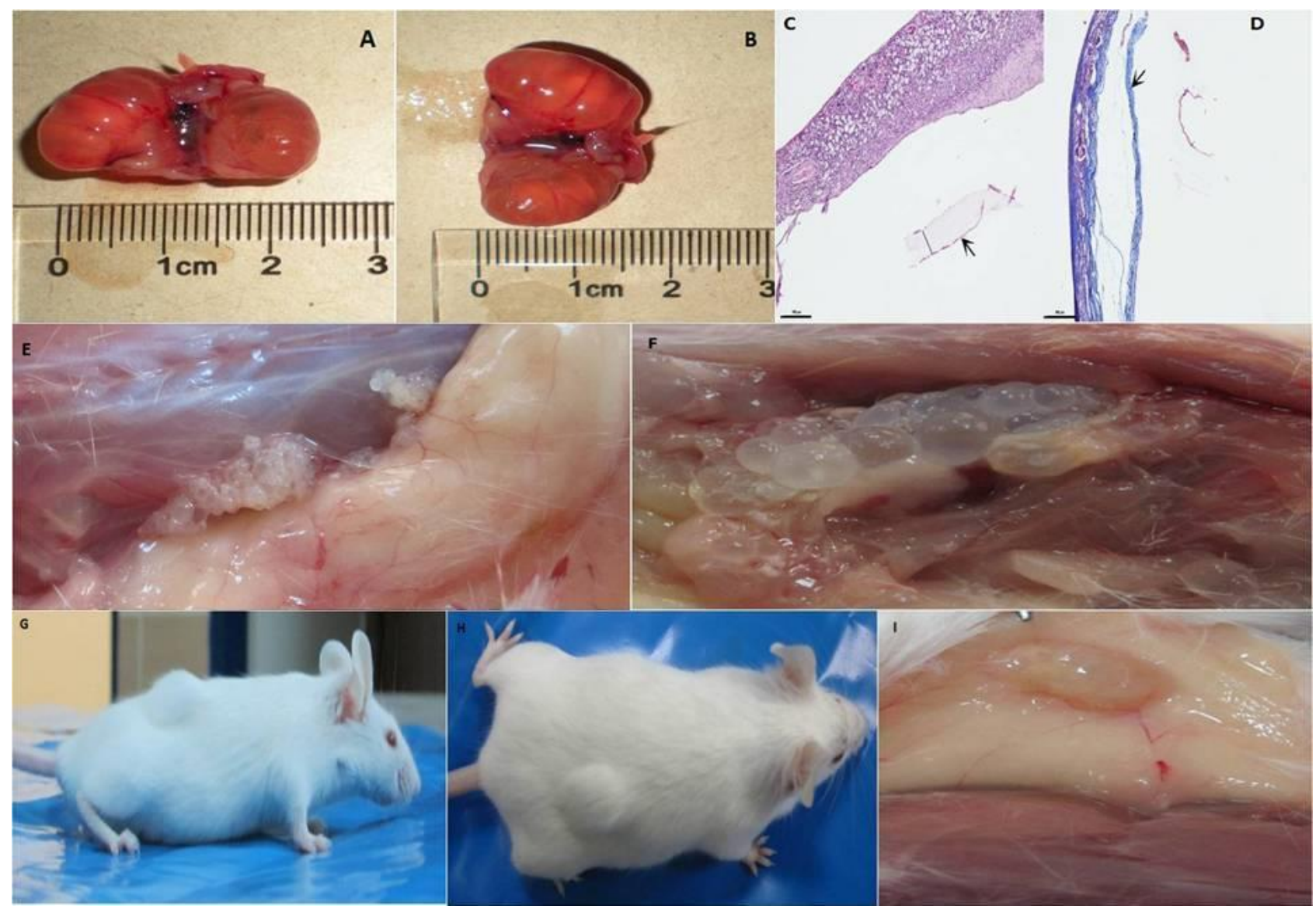

Figure 2. Macroscopic and microscopic findings of study. A-B: Macroscopic appearance of hydatid cysts in both kidneys in intraperitoneal group. C-D: Microscopy of kidney hydatid cysts. Germinal membrane (arrow) and laminar layer (-), haematoxylene eosin (C). Fibrous tissue (arrow), masson trichrome (D). E: Hydatid cysts adjacent to subcutan connective tissue in subcutan group. F: Hydatid cysts localized with intramuscularly. G-H: Appearance of hydatid cyst in subcutan group before necropsy. I: Macroscopic presentation of constantly devoleped hydatid cyst under skin in subcutan group.

Şekil 2. Çalışmanın makroskobik ve mikroskobik bulguları. A-B: Peritoniçi grupta heriki böbrekteki hidatik kistlerin makroskobik görünümü. C-D: Böbrek hidatik kistinin mikroskopisi. Germinal membran (ok) ve laminar katman (-), hematoksilen eozin (C). Fibröz doku (ok), masson trikrom (D). E: Derialtı grupta derialtı bağ dokuya bitişik hidatik kistler. F: Kas içine yerleşmiş hidatik kistler. G-H: Nekropsi öncesi derialtı gruptaki hidatik kistlerin görünümü. I: Derialtı grupta derinin altında gelişmiş hidatik kistin makroskobik görünümü. 
cyst in the eyes and around it. In the current study, we couldn't also generate any hydatid cysts in the eye. This may be releated with intraocular pressure and defence mechanisms in the eye. Cysts in the brain, bone, or eye and calcified cysts often induce no or low antibody responses (3). However, we detected antibody responses in five of seven mice in eye group. The researchers (7), injected protoscoleces by intraperitoneally and detected cysts on the liver and peritoneum. However, we used the same route and found cysts on the kidneys. Breijo et al. (5) were recovered tiny cysts from mice infected with 1000 protoscoleces. However, Mousavi and Tappeh, (7) observed growth rate when infection was done by using a dose of 2000 protoscoleces $/ 0.5 \mathrm{ml}$. Thus, the rate of parasite growth is probably determined by multiple factors such as the origin and metabolic status of the protoscolex and individual factors.

Tabar and Razmi (12) were evaluated the levels of antibody production in mice against three antigens (hydatid cyst fluid protein, protoscolex and adult worms of E. granulosus proteins). Mice were immunized with protoscoleces, did not produce high level of antibody four weeks after the first immunization, whereas antibody produced by cyst fluid and adult worms of $E$. granulosus was roughly 5 and 7 times of before immunization, respectively. In our study, we detected the serpositivity in subcutan $(\mathrm{n}=3)$, oral $(\mathrm{n}=3)$ and eye groups $(n=5)$. In the current study, due to unable to complete the study process, serum samples couldn't be obtained in some mice. Sterile hydatid cysts were macroscopically detected in three mice in subcutan group and seropositivity was found by ELISA in all. It was observed neither macroscopic nor microscopic hydatid cysts in ocular group while seropositivity was detected in five mice. Similarly, neither macroscopic nor microscopic hydatid cysts were detected in oral group while seropositivity was observed in three mice.

In conclusion, evidence from this study suggests that hydatid cyst can be produced by intraperitoneal and subcutaneous but not ocular and oral routes. Secunder hydatid cysts usually reaches to the suitable growth and size but serological response should be considered in each time.

\section{Acknowledgements}

The authors would like to thank to Pathology Laboratory of Veterinary Control and Research Institute in Elazığ for the pathological evaluation of the samples. This study has been supported by a grant from Firat University Scientific Research Projects Unit (Project No: VF.11.06).

\section{References}

1. Akoglu M, Davidson BR (1992): A rational approach to the terminology of hydatid disease of the liver. J Infect, 24, $1-6$.

2. Al-Qaoud KM, Abdel-Hafez SK (2008): The induction of $T$ helper type 1 response by cytokine gene transfection protects mice against secondary hydatidosis. Parasitol Res, 102, 1151-5.

3. Ammann RW, Eckert J (1996): Cestodes: Echinococcus. Gastroenterol Clin North Am, 25, 655-689.

4. Araj GF, Matossian RM, Frayhay GF (1977): The host response in secondary hydatidosis of mice. I. Circulating antibodies. Z Parasitenk, 52, 23-30.

5. Breijo M, Spinelli P, Sim RB, et al. (1998): Echinococcus granulosus: an intraperitoneal diffusion chamber model of secondary infection in mice. Exp Parasitol, 90, 270-6.

6. Culling AF, Allison TR, Barr TW (1985): Cellulary Pathology Technique 4rd. ed. Mid-Country Press, London.

7. Mousavi J, Tappeh KH (2010): Production of experimental hydatid cyst in the eye, peritoneum and liver of Balb/c mice. Acta Parasitol Turcica, 34, 21-23.

8. Oriol R, Williams JF, Perez-Esandi MV, et al. (1971): Purification of lipoprotein antigens of Echinococcus granulosus from sheep hydatid fluid. Am J Trop Med Hyg, 20, 569-574.

9. Simsek S, Koroglu E (2004): Evaluation of enzyme-linked immunosorbent assay (ELISA) and enzyme-linked immunoelectrotransfer blot (EITB) for immunodiagnosis of hydatid diseases in sheep. Acta Trop, 92, 17-24.

10. Simsek S, Koroglu E, Dumanli N, et al. (2005): Seroprevalance of cattle hydatidosis in some countries of East Anatolian Region of Turkey. Tr J Vet Anim Sci, 29, 1305-1310.

11. Smyth JD, Barret NJ (1980): Procedures for testing the viability of human hydatid cyst following surgical removal, especially after chemoterapy. Trans R Soc Trop Med Hyg, 74, 649-652.

12. Tabar GH, Razmi G (2009): Evaluation of antibody against hydatid fluid, protoscolex and adult worms of Echinococcus granulosus antigens by ELISA in mice. Iran J Vet Sci Tech, 1, 27-34.

13. Thompson RCA (1995): Biology and Systematics of Echinococcus. 1-37. In. RCA Thompson, AJ Lymbery, (Eds.) Echinococcus and Hydatid Disease. CAB Int., Oxfordshire, UK.

Geliş tarihi: 14.09.2015 / Kabul tarihi: 12.10.2015
Address for correspondence:
Prof. Dr. Sami Şimşek
University of Firat,
Faculty of Veterinary Medicine,
Department of Parasitology,
23119, Elazı̆g-Turkey.
e-mail: ssimsek@firat.edu.tr 